\title{
Risk factors of cerebral toxoplasmosis in HIV patients: A systematic review
}

\author{
I Made Dwinata ${ }^{1}$, I Putu Eka Widyadharma' ${ }^{2}$, Putri Rossyana Dewi², Eric Hartono Tedyanto ${ }^{2}$ \\ ${ }^{1}$ Department of Parasitology, Faculty of Veterinary Medicine, Udayana University, Denpasar, Bali, Indonesia \\ ${ }^{2}$ Department of Neurology, Faculty of Medicine, Udayana University/Sanglah General Hospital, Bali, Indonesia
}

\begin{abstract}
Introduction. Cerebral toxoplasmosis is one of the diseases of the central nervous system that can occur in people with AIDS. Cerebral toxoplasmosis occupies third place among fatal diseases that can occur in people with AIDS. Prevalence of toxoplasmosis is about $25-30 \%$ of the world's human population, and in Asia it is as high as $40 \%$. Risk factors for devel-oping cerebral toxoplasmosis is needed to be sought to find out risk factors that triggers and acts as protective factors for toxoplasmosis cerebral in HIV-positive patients.

Methods. Two reviewers searched PubMed and Medline to identify cohort, case-control and cross-sectional studies. Two independent reviewers searched the databases, identified studies and extracted data. Inclusion and exclusion criteria were applied for the data screening.

Results. Four studies were included. Two prospective cohort studies, one multicenter cohort study and one case control study. Age was not found to have a role as a risk factor. Gender was shown to have significant in one study (Male vs female OR $0.4795 \% \mathrm{Cl} 0.25-0.88, \mathrm{p}=0.02$ ). CD4 <100 increased the risk of toxoplasmosis by 27.94 times, while CD4 0-50 increased the risk by 10.82 times. HIV viral load $>100.000$ was associated with 5.10 times higher to develop cerebral toxoplasma. Prophylaxis therapy using cotrimoxazole can reduce the risk of cerebral toxoplasmosis.

Conclusion. Age, female sex, low CD4 cell count, and high HIV viral load increase the risk of cerebral toxoplasmosis, whereas ART therapy and prophylaxis with cotrimoxazole can reduce the risk.
\end{abstract}

Keywords: cerebral toxoplasmosis, HIV, risk factors

\section{INTRODUCTION}

The prevalence of central nervous system-related diseases caused by the human immunodeficiency virus (HIV) escalated in recent years. Cerebral toxoplasmosis is one of the diseases of the central nervous system that can occur in people with AIDS. Cerebral toxoplasmosis occupies third place among fatal diseases that can occur in people with AIDS. The causative agent of cerebral toxoplasmosis is Toxoplasma gondii, an opportunistic intracellular parasite that can infect and ruin any nucleated cell. Primaery toxoplasma gondii infections usually are asymptomatic. It only causes mild symptoms for the vast majority of the immunocompetent population. Nevertheless, severe clinical symptoms can occur in rare cases (1).
Prevalence of toxoplasmosis is about $25-30 \%$ of the world's human population, varies widely between regions (from $10 \%$ to $80 \%$ ), within the country, and in different ethnic and social groups. The highest infection rates were reported in South America (42-72\%) and Asia (40\%) (2).

In the early 1990s, cerebral toxoplasmosis was the most common focal brain disorder in HIV-infected persons, with a mean annual incidence of 0.4-0.7 events per 100 persons per year on average and is more common in patients with low CD4+ counts. In 1992-1996, due to the widespread use of prophylactic drugs, there has been a decline in the epidemiology of this disease $(3,4)$.

The purpose of making this systematic review is to find out risk factors that triggers and acts as pro- 
tective factors for toxoplasmosis cerebral in HIV-positive patients.

\section{METHODS}

\section{Data searching}

We conducted a systematic search through $\mathrm{Pu}-$ bMed and Embase according to the protocol developed by PRISMA in conducting a systematic review. We include all published articles describing risk factors for cerebral toxoplasmosis in patients with HIV. We use specific keywords 1. "risk factors" or "risk factor; and 2. "cerebral toxoplasmosis" or "cerebral toxoplasma" or "brain toxoplasma" or "brain toxoplasmosis"; and 3. "HIV" or "human immunodeficiency virus".

\section{Inclusion and exclusion criteria}

We included published original articles with an observational study design (cohort, case-control, or cross-sectional). We excluded articles by the design of randomized controlled trials, descriptive studies, or case reports. First, 1 reviewer will screen the title and abstract of the article, then screen the complete manuscript according to the eligibility criteria

TABLE 1. Inclusion and exclusion criteria

\begin{tabular}{|c|c|c|}
\hline & Inclusion criteria & Exclusion criteria \\
\hline Population & $\begin{array}{l}\text { Cerebral toxoplasmosis } \\
\text { in individual with HIV } \\
\text { infection }\end{array}$ & $\begin{array}{l}\text { HIV infection and } \\
\text { cerebral toxoplasma } \\
\text { was not included in the } \\
\text { individuals }\end{array}$ \\
\hline $\begin{array}{l}\text { Study } \\
\text { design }\end{array}$ & $\begin{array}{l}\text { Cohort } \\
\text { Cross-sectional } \\
\text { Case-control }\end{array}$ & $\begin{array}{l}\text { Randomized-controlled } \\
\text { trial } \\
\text { Case report } \\
\text { Case series } \\
\text { Descriptive studies } \\
\text { Qualitative studies }\end{array}$ \\
\hline Language & English & Other than English \\
\hline Analysis & $\begin{array}{l}\text { Statistical analysis was } \\
\text { provided }\end{array}$ & $\begin{array}{l}\text { There were no } \\
\text { stastitical analysis } \\
\text { given }\end{array}$ \\
\hline
\end{tabular}

\section{Data extraction}

Two reviewers took data from selected articles. The data to be taken are the study population, study design, types of interventions carried out, control variables, and the results of the conclusions of the study. Disagreements from data taken from one reviewer will be resolved by a third reviewer.

\section{RESULTS}

We found 204 journals in our search strategy. In the initial screening, we excluded 103 duplicated journals. In the second screening, titles and abstracts were reviewed according to the eligibility criteria, 56 journals were excluded, the remaining
45 journals. At the third screening, full manuscripts were reviewed, 41 journals were excluded. Eventually, 4 studies met the eligibility criteria and were included in this systematic review. The flow of the search strategy can be seen in Figure 1.

Two review authors independently assessed the risk of bias for each We resolved disagreements by discussion, or by involving a third review author (DD). We assessed risk of bias according to the following domains: allocation concealment, blinding of participants and personnel, blinding of outcome assessment, incomplete outcome data, selective outcome reporting, other bias, which is shown in Figure 2.

\section{Study characteristics}

The studies were conducted in France, UK, Italy, and Brazil. There are 2 cohort studies, 1 case control study, and 1 multicentre study. The number of subject population is about 218 to 5046 subjects. Each study describes the risk factors found in patients, both positive and negative risk factors. The characteristics of the study can be seen in Table 2 .

From the 4 studies included in this review, 3 studies describe demographic risk factors, namely age, gender, ethnicity, risk group, and sexual orientation. All four studies described risk factors for CD4 cell count and HIV viral load. In addition, prophylactic therapy and ART therapy are also described in the 3 published articles. All studies were tested with statistical analysis to see whether these risk factors were statistically or clinically significant (Table 3).

\section{Demographics}

The effect of age and sex on the risk of cerebral toxoplasmosis in HIV patients has been observed. According to CHIC and Antinori et al., age was neither clinically nor statistically significant. According to Antinori et al., female sex is known to be clinically and statistically significant (male vs female OR 0.47 95\% CI 0.25-0.88, $\mathrm{p}=0.02$ ).

\section{Health status}

All studies state that CD4 and HIV viral load results influence risk factors for cerebral toxoplasmosis. in patients with HIV. Antinori stated that each increase in the CD4+ cell count of 50 cells/ml, would reduce the risk of toxoplasmosis by 0.85 times. $\mathrm{Ab}$ grall et al. stated that CD4 $<100$ increased the risk of toxoplasmosis by 27.94 times, while CHIC stated that CD4 0-50 increased the risk by 10.82 times. For HIV viral load, CHIC revealed a statistically and clinically significant result, which was 5.10 times higher when HIV viral load was $>100,000$. 


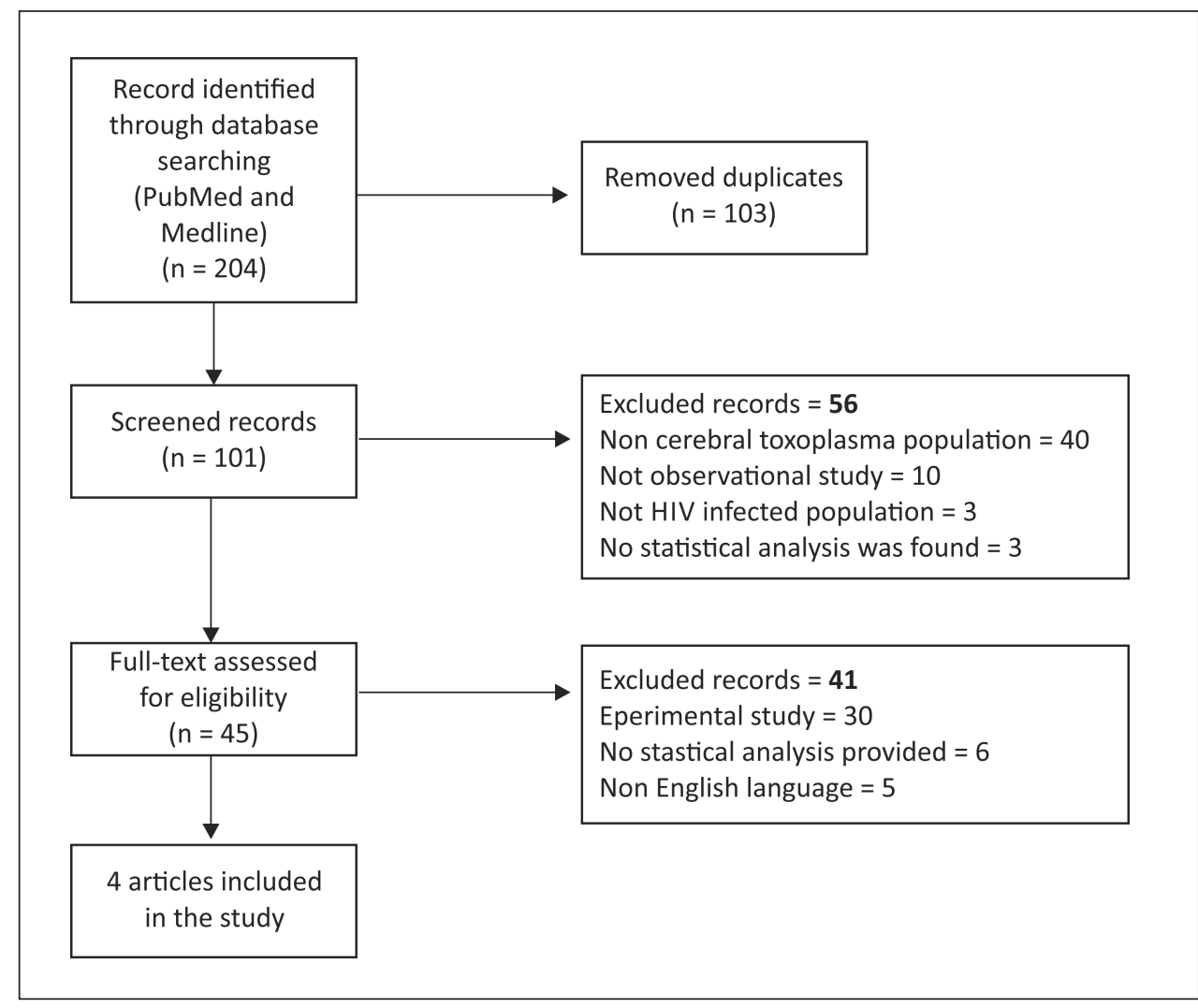

FIGURE 1. PRISMA Flow

diagram quality assessment

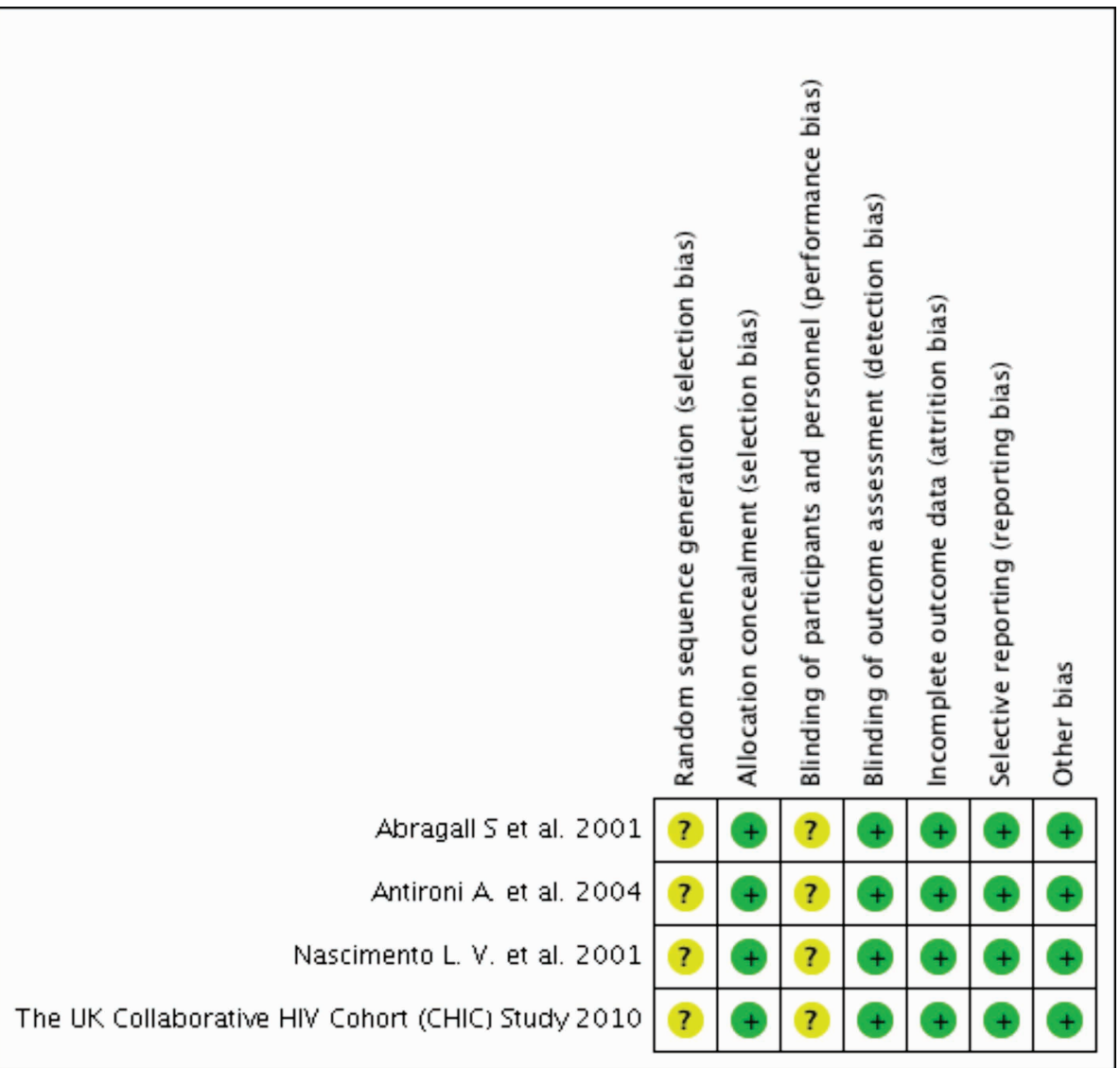

FIGURE 2. Risk of bias summary

\section{Prophylactic therapy}

3 studies contain the benefits of prophylactic therapy for cerebral toxoplasmosis. These three studies states that prophylactic therapy in the form of cotrimoxazole can reduce the risk of cerebral toxoplasmosis. 
TABLE 2. Study characteristics

\begin{tabular}{|c|c|c|c|c|c|c|c|}
\hline Author & Year & Country & Design & $\begin{array}{l}\text { Population } \\
\text { size }\end{array}$ & $\begin{array}{c}\text { TE } \\
\text { patients }\end{array}$ & Risk factor & Statistical \\
\hline $\begin{array}{l}\text { Abgrall S } \\
\text { et al. (3) }\end{array}$ & 2001 & France & $\begin{array}{l}\text { Prospective } \\
\text { cohort study }\end{array}$ & $\begin{array}{c}5,046 \\
\text { patients }\end{array}$ & 57 & $\begin{array}{l}\text { CD4 cell counts, antiretroviral } \\
\text { therapy, Cotrimoxazole } \\
\text { prophylaxis (pre and during } \\
\text { HAART therapy) }\end{array}$ & $\begin{array}{l}\text { Univariate and } \\
\text { multivariable } \\
\text { proportional hazards } \\
\text { regression analyses }\end{array}$ \\
\hline $\begin{array}{l}\text { The UK } \\
\text { Collaborative } \\
\text { HIV Cohort } \\
\text { (CHIC) Study } \\
\text { Steering } \\
\text { Committee (4) }\end{array}$ & 2010 & UK & $\begin{array}{c}\text { Ongoing } \\
\text { cohort study }\end{array}$ & 574 & 184 & $\begin{array}{c}\text { Age, ethnicity, risk group, CD4+, } \\
\text { HIV Viral load }\end{array}$ & $\begin{array}{l}\text { Poisson regression } \\
\text { analysis }\end{array}$ \\
\hline $\begin{array}{l}\text { Antironi A } \\
\text { et al. (5) }\end{array}$ & 2004 & Italy & $\begin{array}{l}\text { Prospective } \\
\text { multicenter } \\
\text { study }\end{array}$ & 573 & 135 & $\begin{array}{c}\text { Age, Sex, Transmission } \\
\text { Route, ART Status, History } \\
\text { of TE prophylaxis, Cognitive } \\
\text { symptoms, Focal Signs, } \\
\text { Meningeal Symptoms, Cerebral } \\
\text { Atrophy, Contrast enhancement, } \\
\text { Mass effect, White matter } \\
\text { involvement, CD+ cell, Plasma } \\
\text { HIV RNA Load }\end{array}$ & $\begin{array}{l}\text { Multivariate logistic } \\
\text { analysis }\end{array}$ \\
\hline $\begin{array}{l}\text { Nascimento LV } \\
\text { et al. (6) }\end{array}$ & 2001 & Brazil & $\begin{array}{l}\text { Case-control } \\
\text { study }\end{array}$ & 218 & 92 & $\begin{array}{c}\text { Gender, Homosexual/bisexual, } \\
\text { CD4 cell count, Cotrimoxazole } \\
\text { prophylaxis, ART }\end{array}$ & $\begin{array}{l}\text { Multiple logistic } \\
\text { regression analysis }\end{array}$ \\
\hline
\end{tabular}

\section{Antiretroviral therapy}

Abgrall et al. and Antinori et al. revealed clinically and statistically significant results, which were 0.66- and 0.49-times greater risk, respectively, when patients received ART therapy.

\section{DISCUSSION}

Two studies in the US examined the prevalence of cerebral toxoplasmosis in HIV patients. The population samples for each study were 169 and 139 women with HIV and $22 \%$ and $20 \%$ reported having cerebral toxoplasmosis, respectively. Falusi et al. revealed that there were about $15.3 \%$ of HIV-infected female patients were seropositive and $14.3 \%$ of women were not infected (7). Basavaraju et al. also revealed that of the $34.78 \%$ HIV-infected patients who were seropositive, about $28.95 \%$ were male and $38.89 \%$ were female and the most common age group was 31-40 years. In this systematic review, it was also found that the prevalence of cerebral toxoplasmosis was 2.12 times more common in women (male vs female OR 0.47 95\% CI $0.25-0.88, \mathrm{p}=0.02$ ) (8).

The use of antiretroviral drugs (ART) can significantly reduce the incidence of cerebral toxoplasmosis in HIV-infected patients. In Brazil, where HIV prevalence was around $0.4 \%$ in 2014, there was a significant decline in the incidence after the widespread use of antiretroviral drugs. The mortality rate due to cerebral toxoplasmosis also decreased, namely in the pre-ART era around $90 \%$ and in the post-ART era to $15-30 \%$ (9).
There is a correlation between CD4 cell count and the incidence of cerebral toxoplasmosis. In a study conducted by Basavaraju et al., there were about $75 \%$ of people with toxoplasmic IgG patients with CD4 counts of 51-100 and no neurological symptoms (8). Osunkalu et al. reported that approximately $79.4 \%$ of HIV-positive patients were asymptomatic and had CD4 cell counts $<100$ (10). Pauwels et al. showed that $79 \%$ of patients with neurologic and seropositive symptoms had CD4 counts $<150$ cells $/ \mathrm{mm}^{3}$. Sucilathangam et al. also reported several patients with CD4 count $<100$ cells/mm3 and toxoplasmosis seropositive (11). This finding is also correlated with other studies (12). Abgrall et al. stated that $\mathrm{CD} 4<100$ increased the risk of toxoplasmosis by 27.94 times, while CHIC stated that CD4 0-50 cells/mm3 increased risk by 10.82 times (5).

The risk of developing cerebral toxoplasmosis is significantly increased in HIV-infected patients, have a CD4 cell count $<100$ cells/mm3, and do not receive effective and regular prophylactic therapy (5). In HIV-infected patients who are severely immunocompromised (CD4<200 cells/mm3) accompanied by appropriate clinical and radiological features, should receive anti toxoplasma therapy. Early detection and treatment as soon as possible can reduce the risk of sequelae and mortality (12).

The effectiveness of prophylactic therapy in preventing the incidence of cerebral toxoplasmosis has been known. A study revealed that prophylactic therapy reduces the risk of cerebral toxoplasmosis by $46 \%$. Even in the era of ART, cerebral toxoplasmosis prophylaxis will remain a major factor in re- 
TABLE 3. Risk factors for cerebral toxoplasma in HIV infected individuals

\begin{tabular}{|c|c|c|c|c|c|c|c|}
\hline Category & Author & Variable & Definition & $\begin{array}{l}\text { Effect } \\
\text { size }\end{array}$ & $95 \% \mathrm{Cl}$ & $P$ value & $\begin{array}{l}\text { Measure- } \\
\text { ment }\end{array}$ \\
\hline \multirow[t]{5}{*}{ Demography } & $\begin{array}{l}\text { The UK } \\
\text { Collaborative HIV } \\
\text { Cohort (CHIC) } \\
\text { Study Steering } \\
\text { Committee (4) }\end{array}$ & Age & $\begin{array}{l}<30 \text { (ref) } \\
30-39 \\
40-49 \\
>49\end{array}$ & $\begin{array}{l}- \\
0.98 \\
1.06 \\
1.19\end{array}$ & $\begin{array}{l}- \\
0.66-1.46 \\
0.67-1.69 \\
0.64-2.18\end{array}$ & 0.91 & $\mathrm{RR}$ \\
\hline & $\begin{array}{l}\text { Antinori A } \\
\text { et al. (5) }\end{array}$ & Ethnicity & $\begin{array}{l}\text { White (ref) } \\
\text { Black African } \\
\text { Other }\end{array}$ & $\begin{array}{l}- \\
2.76 \\
2.29\end{array}$ & $\begin{array}{c}- \\
1.71-4.43 \\
1.40-3.75\end{array}$ & 0.0001 & $\mathrm{RR}$ \\
\hline & $\begin{array}{l}\text { Nascimento LV et } \\
\text { al. (6) }\end{array}$ & Risk Group & $\begin{array}{l}\text { MSM (ref) } \\
\text { IDU } \\
\text { Heterosexual }\end{array}$ & $\begin{array}{l}- \\
1.79 \\
2.95\end{array}$ & $\begin{array}{c}- \\
0.98-3.92 \\
1.61-5.43\end{array}$ & 0.0001 & $\mathrm{RR}$ \\
\hline & & $\begin{array}{l}\text { Age } \\
\text { Sex } \\
\text { Transmission } \\
\text { Route }\end{array}$ & $\begin{array}{l}>35 \\
\text { Male vs female } \\
\text { Sexual vs IDU }\end{array}$ & $\begin{array}{l}0.97 \\
0.47 \\
1.23\end{array}$ & $\begin{array}{l}0.51-1.81 \\
0.25-0.88 \\
0.72-2.11\end{array}$ & $\begin{array}{l}0.93 \\
0.02 \\
0.45\end{array}$ & OR \\
\hline & & $\begin{array}{l}\text { Gender } \\
\text { Risk group }\end{array}$ & $\begin{array}{l}\text { Male } \\
\text { Homosexual/bisexual }\end{array}$ & $\begin{array}{l}1.32 \\
1.65\end{array}$ & $\begin{array}{l}0.54-3.19 \\
0.71-3.82\end{array}$ & $\begin{array}{l}0.54 \\
0.24\end{array}$ & $\begin{array}{l}\text { OR } \\
\text { OR }\end{array}$ \\
\hline \multirow[t]{7}{*}{ Health status } & $\begin{array}{l}\text { Abgrall S } \\
\text { et al. (3) }\end{array}$ & CD4 cell counts & $<100$ & 27.94 & $11.91-65.51$ & 0.001 & $\mathrm{RH}$ \\
\hline & $\begin{array}{l}\text { The UK } \\
\text { Collaborative HIV } \\
\text { Cohort (CHIC) } \\
\text { Study Steering } \\
\text { Committee (4) }\end{array}$ & CD4+ & $\begin{array}{l}0-50 \\
50-199 \\
200-349 \text { (ref) } \\
350-499 \\
>500\end{array}$ & $\begin{array}{c}10.82 \\
2.82 \\
- \\
0.13 \\
0.05\end{array}$ & $\begin{array}{c}(6.12,19.14) \\
(1.60,5.00)\end{array}$ & 0.0001 & $\mathrm{RR}$ \\
\hline & Antinori A et al. (5) & HIV Viral load & $\begin{array}{l}<50 \text { (ref) } \\
51-10.000 \\
10.000-100.000 \\
>100.000\end{array}$ & $\begin{array}{l}- \\
0.96 \\
1.69 \\
5.10\end{array}$ & $\begin{array}{c}- \\
(0.03,0.54) \\
(0.01,0.41)\end{array}$ & 0.0001 & $\mathrm{RR}$ \\
\hline & $\begin{array}{l}\text { Nascimento LV et } \\
\text { al. (6) }\end{array}$ & CD+ cell & $\begin{array}{l}\text { For each increase in the } \\
\text { CD4+ cell count of } 50 \\
\text { cells } / \mathrm{mL}\end{array}$ & 0.85 & $\begin{array}{c}- \\
(0.40,2.29) \\
(0.76,3.75) \\
(2.53,10.27)\end{array}$ & 0.01 & ORO \\
\hline & & $\begin{array}{l}\text { Plasma HIV RNA } \\
\text { Load }\end{array}$ & $\begin{array}{l}\text { For each increase in the } \\
\text { plasma HIV RNA load of } \\
1.0 \log 10 \text { copies/mL }\end{array}$ & 1.03 & $(0.75-0.97)$ & 0.83 & OR \\
\hline & & CD4 cell count & $\begin{array}{l}>400 \text { (ref) } \\
200-399 \\
100-199 \\
<100\end{array}$ & $\begin{array}{c}1 \\
4.79 \\
10.2 \\
37.09 \\
\end{array}$ & $(0.81-1.30)$ & $\begin{array}{c}- \\
0.06 \\
0.005 \\
<0.0001\end{array}$ & OR \\
\hline & & & & & $\begin{array}{c}- \\
0.94-24.44 \\
2.00-51.90 \\
7.49-183.67\end{array}$ & & \\
\hline \multirow[t]{3}{*}{ ART status } & $\begin{array}{l}\text { Abgrall S } \\
\text { et al. (3) }\end{array}$ & $\begin{array}{l}\text { Antiretroviral } \\
\text { therapy }\end{array}$ & HAART vs none & 0.66 & $0.50-0.86$ & 0.002 & $\mathrm{RHO}$ \\
\hline & $\begin{array}{l}\text { Antinori A. } \\
\text { et al. (5) }\end{array}$ & ART Status & $\begin{array}{l}\text { ART status at diagnosis, } \\
\text { experienced vs. naïve }\end{array}$ & 0.49 & $(0.26-0.91)$ & 0.02 & OR \\
\hline & $\begin{array}{l}\text { Nascimento LV et } \\
\text { al. (6) }\end{array}$ & ART & ART therapy & 0.67 & $0.29-1.57$ & 0.36 & OR \\
\hline \multirow[t]{3}{*}{ Prophylaxis } & $\begin{array}{l}\text { Abgrall S } \\
\text { et al. (3) }\end{array}$ & prophylaxis & Cotrimoxazole & 0.47 & $0.26-0.85$ & 0.01 & $\mathrm{RH}$ \\
\hline & $\begin{array}{l}\text { Antironi A } \\
\text { et al. (5) }\end{array}$ & $\begin{array}{l}\text { History of TE } \\
\text { prophylaxis }\end{array}$ & Cotrimoxazole & 0.47 & $(0.24-0.90)$ & 0.02 & OR \\
\hline & $\begin{array}{l}\text { Nascimento LV et } \\
\text { al. (6) }\end{array}$ & prophylaxis & Cotrimoxazole & 0.3 & $0.15-0.60$ & 0.001 & OR \\
\hline
\end{tabular}


ducing disease incidence. Prophylaxis should be discontinued in patients receiving therapy (5). The three studies included in this systematic review also stated that prophylactic therapy in the form of cotrimoxazole can reduce the risk of cerebral toxoplasmosis.

Cerebral toxoplasmosis is the most common opportunistic infection of the central nervous system (13). The incidence of cerebral toxoplasmosis increased significantly in CD4 cell counts below 100, p $<0.001$, and in HIV viral loads above 50 viral load. However, the frequency of identification of cerebral toxoplasmosis was significantly reduced among patients on ART for more than 1 year (1). Abgrall et al. and Antinori et al. also revealed statistically and clinically significant results, which were 0.66 and 0.49 times greater risk, respectively, when patients received antiretroviral therapy.
There are several limitations to this systematic review. First, the number of studies that met the eligibility criteria was only 4 , so that more scientific evidence is needed to determine the risk factors for cerebral toxoplasmosis in patients with HIV. We hope that this systematic review can provide information about the risk factors for cerebral toxoplasmosis in patients with HIV and become a reference for conducting future studies.

\section{CONCLUSION}

Age, female sex, low CD4 cell count, and high HIV viral load increase the risk of cerebral toxoplasmosis, whereas ART therapy and prophylaxis with cotrimoxazole can reduce the risk.

Conflict of interest: none declared Financial support: none declared

\section{REFERENCES}

1. Azovtseva OV, Viktorova EA, Bakulina EG, Shelomov AS, Trofimova TN. Cerebral toxoplasmosis in HIV-infected patients over 2015-2018 (a case study of Russia). Epidemiol Infect. 2020 May 4;148:e142.

2. Pappas G, Roussos N, Falagas ME. Toxoplasmosis snapshots: Global status of Toxoplasma gondii seroprevalence and implications for pregnancy and congenital toxoplasmosis. Int J Parasitol. 2009;39(12):1385-94.

3. Abgrall S, Rabaud C, Costagliola D. Incidence and risk factors for toxoplasmic encephalitis in human immunodeficiency virus-infected patients before and during the highly active antiretroviral therapy era. Clin Infect Dis. 2001;33(10):1747-55.

4. Garvey L. HIV-associated central nervous system diseases in the recent combination antiretroviral therapy era. Eur J Neurol. 2011; 18(3):527-34.

5. Antinori A, Larussa D, Cingolani A, Lorenzini P, Bossolasco S, Finazzi $M G$, et al. Prevalence, associated factors, and prognostic determinants of AIDS-related toxoplasmic encephalitis in the era of advanced highly active antiretroviral therapy. Clin Infect Dis. 2004;39(11):1681-91.

6. Nascimento L V., Stollar F, Tavares LB, Cavasini CE, Maia IL, Cordeiro JA, et al. Risk factors for toxoplasmic encephalitis in HIV-infected patients: A case-control study in Brazil. Ann Trop Med Parasitol. 2001;95(6):587-93.

7. Falusi $\mathrm{O}$, French AL, Seaberg EC, Tien PC, Watts DH, Minkoff $\mathrm{H}$, et al. Prevalence and predictors of Toxoplasma seropositivity in women with and at risk for human immunodeficiency virus infection. Clin Infect Dis. 2002;35(11):1414-7.

8. Basavaraju A. Toxoplasmosis in HIV infection: An overview. Trop Parasitol. 2016;6(2):129-35.

9. Vidal JE. HIV-Related Cerebral Toxoplasmosis Revisited: Current Concepts and Controversies of an Old Disease. J Int Assoc Provid AIDS Care. 2019;18.

10. Osunkalu VO, Akanmu SA, Ofomah NJ, Onyiaorah I V., Adediran AA, Akinde RO, et al. Seroprevalence of Toxoplasma gondii IgG antibody in HIV-infected patients at the lagos university teaching hospital. HIV/ AIDS - Res Palliat Care. 2011;3:101-5.

11. Pauwels A, Meyohas MC, Eliaszewicz M, Legendre C, Mougeot G, Frottier J. Toxoplasma Colitis in the Acquired Immunodeficiency Syndrome. Am J Gastroenterol. 1992;87(4):518-9.

12. Sucilathangam G, Palaniappan N, Sreekumar C, Anna T. Serological survey of toxoplasmosis in a district in Tamil Nadu: Hospital-based study. Indian J Med Res. 2013;137(3):560-3.

13. Tan IL, Smith BR, von Geldern G, Mateen FJ, McArthur JC. HIVassociated opportunistic infections of the CNS. Lancet Neurol. 2012;11(7):605-17. 